IZA DP No. 5650

China's Latent Human Capital Investment: Achieving Milestones and Competing for the Top

Amelie F. Constant

Bienvenue $\mathrm{N}$. Tien

Klaus F. Zimmermann

Jingzhou Meng

April 2011 


\title{
China's Latent Human Capital Investment: Achieving Milestones and Competing for the Top
}

\author{
Amelie F. Constant \\ DIWDC, George Washington University and IZA \\ Bienvenue N. Tien \\ DIWDC \\ Klaus F. Zimmermann \\ IZA and University of Bonn \\ Jingzhou Meng \\ George Washington University
}

Discussion Paper No. 5650

April 2011

IZA

P.O. Box 7240

53072 Bonn

Germany

Phone: +49-228-3894-0

Fax: +49-228-3894-180

E-mail: iza@iza.org

\begin{abstract}
Any opinions expressed here are those of the author(s) and not those of IZA. Research published in this series may include views on policy, but the institute itself takes no institutional policy positions.

The Institute for the Study of Labor (IZA) in Bonn is a local and virtual international research center and a place of communication between science, politics and business. IZA is an independent nonprofit organization supported by Deutsche Post Foundation. The center is associated with the University of Bonn and offers a stimulating research environment through its international network, workshops and conferences, data service, project support, research visits and doctoral program. IZA engages in (i) original and internationally competitive research in all fields of labor economics, (ii) development of policy concepts, and (iii) dissemination of research results and concepts to the interested public.
\end{abstract}

IZA Discussion Papers often represent preliminary work and are circulated to encourage discussion. Citation of such a paper should account for its provisional character. A revised version may be available directly from the author. 
IZA Discussion Paper No. 5650

April 2011

\section{ABSTRACT}

\section{China's Latent Human Capital Investment: Achieving Milestones and Competing for the Top ${ }^{*}$}

In this paper we provide an overview of China's human capital strategy and educational achievements over the last two decades. While every one acknowledges China as an economic superpower, very few are aware of or realize China's notable achievements in education as well as its internationalization of education. Since 1978, the landmark for the foundation of the Chinese modern higher education system China has made tremendous strides in education both domestically and internationally. While China maintains $10 \%$ growth in GDP, albeit with a GDP per capita at the low level of a developing country, it is also producing serious scholars and a tremendous amount of scholarly output; more and more Chinese students seek higher education abroad; and international students find a rising interest in receiving education in China.

JEL Classification: F22, J24, N35, O15, O24, O53

Keywords: China, human capital, brain drain, higher education

Corresponding author:

Amelie Constant

DIWDC

1800 K Street, NW

Suite 716

Washington, DC 20006

USA

E-mail: constant@diwdc.org

\footnotetext{
* Revised version of IZA Policy Paper No. 19, September 2010. We wish to thank Richard Easterlin, Yang Yumei and one referee for encouragement and helpful suggestions on an earlier draft.
} 
"Science has no boundaries. China's endeavors in science and technology need to be more integrated with those of the world, and the world needs a China that is vibrant and able to deliver more in science and technology. Just as collisions generate sparks, exchange and communication enrich imagination and creativity" (Premier Wen Jiabao, 2008).

\section{Introduction}

China is known, acknowledged and revered because of its strong economic ascension. In 2010, China became the second largest national economy and the second largest exporter. ${ }^{1}$ It also has the world's largest current account surplus and foreign exchange reserves, thus being "far more deeply integrated into the world economy than either of the economic superpowers" (Bergsten et al., 2009, p. 9).

While achieving the title of economic superpower is impressive, combining it with the status of being a cocoon of innovation and information technology and of incubating human capital is even more striking. Fewer people, however, are aware of China's impressive strides in human capital investment and its notable achievements in education. Currently, China is spending, on average, more on research and development than any other major developed economy in the West. It is becoming an attraction pole for expatriates and international students alike and a pioneer in producing scientific papers in natural sciences and engineering. In 2007, $59 \%$ of the scientific papers published by Chinese scholars were in natural sciences. In its twelfth five-year plan for 2011-15 China reveals that it attempts to become by 2050 the world champion in science and research.

This paper will document that China has made notable achievements in accumulating human capital. We further seek to identify the strategy which China follows to close up to the USA, Japan and Germany's human capital production. We suggest that capacity building by internationalization is the core of the Chinese science policy. We start by providing an overview of China's human capital strategy and its painstaking commitment to fostering and speeding up the progress of science and technology. We continue with China's internationalization of education and its evolvement over the last 30 years. The following section looks at China as a magnet for international talents. In the last section we summarize China's achieved milestones and conclude with possible implications for the $21^{\text {st }}$ century.

\footnotetext{
${ }^{1}$ China recently surpassed Germany and became the largest exporter.
} 


\section{Investing in Human Capital and Conquering the World}

\section{1. China's Tumultuous Love Affair with Education}

Access to higher education was not open to ordinary people until late into the $19^{\text {th }}$ century, when the first modern Chinese higher institution was established during the Qing Dynasty (18711908). ${ }^{2}$ During the Republican Era of 1912-1949 and with the newly founded higher education system, Western university models began to gain in popularity, and Chinese students were sent abroad to learn advanced technologies. By 1949, 205 universities had been founded in China (Brandenburg and Zhu, 2007). The beginning of the People’s Republic of China (PRC) in 1949 heralded an end to the educational expansion; and by 1953 the number of comprehensive universities had fallen from 49 to 13 . Only colleges specializing in applied subjects such as medicine and agriculture were spared as they were regarded vital for economic development (Ouyang, 2004). During the Cultural Revolution of 1966-1976 China's higher education system suffered further in the hands of political meddling. Many universities were forced to close between 1966 and 1971. Shortly after they were allowed to reopen, but the emphasis was to be on political studies rather than a standard college curriculum (Zhang et al., 2007).

Meng and Gregory (2007) studied the educational cost of the large scale school interruptions due to the Chinese Cultural Revolution. They estimated that those who did not obtain a university degree, because of the Cultural Revolution, lost an average of more than 50\% of potential earnings. Men and women alike suffered reduced attainment of senior high school certificates and more than $20 \%$ prematurely stopped their education process at junior high school level. Interestingly, these education responses do not appear to command lower earnings. While at each level of education attainment most of the cohort experienced missed or interrupted schooling, the authors find that, once they control for the education certificate attained, the impact on earnings of these missed years of schooling or lack of normal curricula was small.

Deng Xiaoping’s renowned Gai Ge Kai Fang, or 'opening-up policy' in the late 1970s brought about many reforms, which put education back on course. Human capital was deemed to be of paramount importance as education could turn China into a global, economic power. In a

\footnotetext{
${ }^{2}$ For an extended historic overview of China’s education, see Constant et al. (2010).
} 
concerted effort, the Chinese government has taken concrete steps to protect it and advance it. A two-way street approach was to be implemented: that of learning from the West and that of attracting the West to China. In 1977 China resumed the National College Entrance Examination, granting more people the opportunity of higher education (Mullins, 2005). The

academic system was based on British and American models, with associate degrees offered by short-cycle colleges, and bachelor's, master's and doctoral degrees granted by standard institutions of higher education; a post-doctoral research system was also enacted. All of which signaled a new phase in modern Chinese higher education.

The Chinese government had also been encouraging students to study abroad, with the availability of various scholarships. However, recipients had to return to China after graduating and work for at least two consecutive years, or face a severe penalty. In addition, the quota that stipulated the number of students studying abroad who financed their own studies and supported themselves was relaxed by the end of 1986. The government even pledged to "support students and scholars studying abroad, encourage them to return to China after their completion of studies and guarantee them the freedom of coming and going" (Ministry of Education of the People's Republic of China, n.d.).

\section{2. China's Domestic Education and the Internationalization of Education}

By the 1990s China has made tremendous strides in advancing its education system and in educating its people. Still, using 1995 data on public expenditures on education as shares of GDP, Heckman (2003) found that China had only spent about 2.5\% of its GDP on human capital investment. In stark contrast, China had devoted roughly 30\% of its GDP to physical capital investment. The resulting ratio of annual investment in physical capital to human capital was much higher than in most other countries in the world. Heckman heavily criticized China's underinvestment in human capital at the expense of over-investment in physical capital. This imbalance, he said, is "symptomatic of a serious distortion in current policy that serves to retard economic development in China” (Heckman, 2003, p. 795).

Nonetheless, China continued on its strategic course of expanding higher education as prescribed. Employing newly available Chinese micro-data Heckman and Li (2004) estimated the returns to college education in China in 2000. They find substantial heterogeneity in returns 
to schooling: people sort into schooling according to their comparative advantage. This finding has become an empirically important phenomenon in modern Chinese labor markets. The authors find that the effect of college attendance on a randomly selected person is an $11 \%$ annual increase in earnings in the urban areas; the effect on those who go to college is actually higher (13\%). They conclude that China's economic reform with pronounced market orientated economic directives over the past 20 plus years has significantly increased returns to education in the 2000s.

Moreover, the Chinese directive on education affected the education opportunities of various population groups and the labor market. Based on 2005 Census data, Li and Xing (2010) find that higher education expansion increased the probability of going to college for some groups. While minority females, those from the central-western region and from rural areas were less likely to benefit from it, one-child families were more responsive to this policy. Education expansion decreased the within sector inequality of those with above high school (inclusive) education mostly because of the increase of the income level for high school graduates.

After the return of Hong Kong to mainland China in 1997, China's higher education entered a new phase of internationalization. Chinese and Western universities started cooperating, and a growing number of Chinese students went abroad to study. In 2003 the Chinese Government started offering scholarships to outstanding students who were financing their own studies (Yao, 2004). These scholarships were open to all Chinese citizens who had shown an excellent academic performance and respected the recipients' choice after graduation in case they wanted to stay abroad. However, scholarships were only given for doctoral programs, and the $\$ 5,000$ grant could not be awarded to the same recipient twice (NesoChina, 2008). By 2007 China had established educational relationships with 188 countries and regions all over the world (2008 China Education Yearbook), and agreements on the mutual recognition of academic degrees had been signed with 32 countries and regions in the world. Further steps to strengthen international ties resulted in the establishment of Confucius Institutes, which are centers for the promotion of Chinese language and culture. By the end of November 2009, the number of such centers had reached 282 and could be found in 84 countries and regions abroad, with 94 in Europe and 87 in America. ${ }^{3}$

\footnotetext{
${ }^{3}$ Source: http://www.hanban.org/node_10961.htm
} 


\section{China and the International Circulation of Students and Scholars}

Since 1978, the number of higher education institutions has increased from 600 to more than 2,000 in 2008, accompanied by an even more dramatic increase in student enrollment to 20 million in 2008 (National Bureau of Statistics of China, 2009). At the same time, the body of students and scholars studying abroad - called 'expatriate brains' - as well as the body of international students studying in China - called 'lured in brains' - have witnessed rapid developments.

\section{1. Trends and Distributions of Chinese Students Abroad}

Depending on the type of funding they have, Chinese students studying overseas can be broadly put into two categories: those officially sponsored by the government and those who support themselves. The first category can be further divided into two groups: state-sponsored students, sent overseas by the Ministry of Education (MoE); and organization-sponsored students, supported by provincial governments or companies (Yao, 2004). In the beginning of the opening-up reform era, most Chinese students overseas were officially sponsored, as they lacked financial resources to support their studies abroad. However, the introduction of the loose policy in 1986 and the fast economic growth in the $21^{\text {st }}$ century reduced limitations for self-supported students.

In 2000, 38,989 Chinese students ${ }^{4}$ went overseas. The majority of them were selfsupported (82.8\%), followed by those who were financially supported by organizations (10.0\%) and by the government (7.2\%). In 2008, the number of Chinese students who went abroad was 179,800; a more than a four-fold increase. Self-supported students accounted for a whopping $89.9 \%$ of the outgoing students. The percentage of students receiving organizational support was $4.8 \%$ and $6.2 \%$ of the students were financially supported by the government. With the year 2000 as the reference year, Figure 1 illustrates the overall number of Chinese students overseas since 2000 by type of financial sponsorship. While the number of self-supported students is

\footnotetext{
${ }^{4}$ Note that we refer to students from mainland China; students from Hong Kong are not included in any of the statistics on education.
} 
clearly above the others and keeps increasing, it is the number of government supported students that exhibits the fastest pace especially, after 2005. This affirms the Chinese government's continual effort to support students going abroad. However, the number of students supported by organizations is dwindling down after 2005.

Not only has the number of Chinese students studying abroad increased, but Chinese students are now to be found in 108 countries and regions all over the world (MoE, n.d.). While their preferred destinations vary with time, they mostly favor Western countries, especially English-speaking ones. Table 1 documents that the top five destinations of Chinese students in 2008 were the USA, the UK, France, Australia and Germany. The USA is by far the most popular destination for Chinese students. In terms of absolute numbers, in 2008, 419,109 Chinese students went abroad for tertiary education. Out of the five preferred destination countries, higher education institutions of the USA alone received 110,246 Chinese students, followed by Australia $(57,596)$, the UK $(45,356)$, Germany $(21,977)$ and France $(20,852)$. That makes about $26.3 \%$ for the USA, $13.7 \%$ for Australia, $10.8 \%$ for the UK, $5.2 \%$ for Germany and $5.0 \%$ for France relative to the entire Chinese students' population going abroad. However, examining the presence of Chinese students from the host country perspective, one observes that out of the entire foreign students population in the United States, they represent about 18\%, 25\% in Australia, 13.7\% in the UK, $11.6 \%$ in Germany, and 8.6\% in France. So Chinese students are largely in the USA, but among the foreign students they have their strongest relative presence in Australia.

Figure 2 (assuming $1999=100$ ) depicts the flow of Chinese students at the tertiary level by the top 5 destination countries ${ }^{5}$ over the period 1999-2008. While the flow of students to the USA has remained almost constant, there has been a rapid ten to twelve-fold increase of students going to the UK, France and Australia. First, it is interesting to note the UK's dominant role as a top 5 destination country. The impressive increase in the number of students going to the UK reached a maximum in 2005; it has been slowly decreasing since then. Nonetheless, the UK is still a favorite destination because of its - perceived by the Chinese - prestigious and high quality education. According to the British Council’s Vision 2020 (Böhm et al., 2003, p. 36),

\footnotetext{
${ }^{5}$ Note that the country comparsion choice here and in the sequel is driven by data availability (in the used data source) and by the empirical observation who are the most important countries or regions in the analyzed case.
} 
Chinese students will be the UK's number one source of international students after 2010, with an annual growth rate of $11.4 \%$.

Second, Figure 2 shows that the number of students going to France has followed an impressive up-sloping curve: while only 2,000 Chinese students chose France in 2000, 12,000 went in 2004 and 21,000 in 2008. Burgeoning bilateral agreements between French and Chinese institutions and universities to support the international exchange of students between the two countries have certainly contributed to this trend. Australia is the present and future favorite of Chinese students, as flows have been rising steeply since 2002. Lastly, the promising rise in the number of students going to Germany has been short-lived. Undoubtedly, the number of Chinese students enrolled in tertiary education in Germany has tripled from 2000 to 2008. While flows have been increasing since 2000, albeit at a rather slow pace, they reached a maximum in 2005 and started decreasing after 2005. As German policymakers debate about charging higher tuition fees to international students, ${ }^{6}$ Chinese students clearly show that they prefer to go to other countries to study.

Figure 3 illustrates the portions of graduate and undergraduate students from mainland China who were enrolled in American schools juxtaposing the academic years 2006/2007 and 2008/2009. It is clear that the number of students enrolled in graduate education is the highest in both academic years, supporting the perception that graduate education obtained in Western universities is very prestigious in China. However, comparing the percentage change of graduates to that of the undergraduates in these two academic years, Figure 3 shows that while the graduates increased by $17 \%$, the undergraduates increased by $62 \%$. Put it differently, while the share of graduate students as a percentage of the entire Chinese student body fell from $70.83 \%$ in $2006 / 2007$ to only $58.48 \%$ in $2008 / 2009$, the share of undergraduates as a percentage of the entire Chinese student body increased from $14.7 \%$ in 2006/2007 to $26.7 \%$ in 2008/2009. Therefore, while the total number of undergraduates is far smaller than the number of graduate students, these statistics indicate strong demand for American education at the undergraduate level. Equally notable is the number of Chinese students with Optional Practical Training (OPT) status. ${ }^{7}$ While in 2006/2007 2,573 Chinese students who graduated from American Colleges and

\footnotetext{
${ }^{6}$ See http://www.spiegel.de/unispiegel/studium/0,1518,680051,00.html.

${ }^{7}$ OPT status allows international students who graduate from American universities to stay in the USA and work for a maximum of 12 months after graduating.
} 
Universities stayed to work for a year in the USA, their number almost quadrupled in 2008/2009 to 8,212 .

\section{2. How China Deals with its Talented Students Going Abroad}

It is said that whoever wins the battle over talents will be the victor in the $21^{\text {st }}$ Century. The statistics presented above allude to some kind of brain drain for China. The pertinent question is then, how does the Chinese government deal with this possibility? This section documents the systematic steps taken towards the return of the talented Chinese living abroad.

Acknowledging a looming brain drain, China’s Premier Wen (2008) said that the "future of China's science and technology depends fundamentally on how we attract, train, and use young scientific talents today. Thus, at the core of our science and technology policy is attracting a diverse range of talents, especially young people, into science and providing them with an environment that brings out the best of their creative ideas.” (Wen, 2008, p. 649).

Since 1990, the Chinese government and the MoE have initiated, sponsored and carried through various programs to encourage highly talented Chinese expatriates to return and contribute to the country's economic reform and human capital. These programs have a wide range, covering young students and middle-aged scholars alike, and short-term visits or permanent stays. The most famous among them is the Chunhui Program (literally, Spring Bud), which - by the end of 2003 - had funded more than 8,000 individuals and 90 groups of scholars and researchers who returned on a short-term visit (MoE, n.d.). Table 2 lists the main programs in the 1990s and early 2000s.

In December 2008 the Chinese central government set the bar higher in terms of attracting la crème de la crème by launching the 'One Thousand Talents Scheme.' This scheme aimed at attracting three groups of the most talented. Those "who (1) have an academic title equivalent to professor in internationally well-known universities and institutions, or (2) work as senior managing staff within a well-known international company or banking institution, or (3) have developed technologies and patents and established their own business abroad" (Zhao and Zhu, 2009, p. 327). It is worth mentioning here that there is a division of tasks between the central and local governments in terms of attracting the most talented people to China. While the 
central government has indeed placed priority on recruiting top scientists and academics, local governments are more active in attracting high-tech entrepreneurs (Zhao and Zhu, 2009).

These great efforts to attract expatriates along with the 'China opportunity theory, which results from China's continual double-digit GDP growth and its recent growing global influence, have enticed more and more Chinese students overseas to return and live their 'American dream' in China. Figure 4 depicts the ratio of the annual flow of Chinese returnees to the flow of students leaving to study abroad in reference to GDP per capita (in Yuan). The positive comovement between economic development and the Returnees-Student Abroad ratio is striking. Over the last 10 years, although the number of Chinese students studying abroad is higher than those who return home, the ratio of those who returned to those going abroad to study has been increasing. It has been also exactly following the GDP per capita evolution of the country. For instance, in 1999, 32.6\% or almost one in three Chinese students returned home, with a GDP per capita for about 7,000 Yuan. In 2008, China’s GDP per was about 22,000 Yuan, and the ratio of Returnees and Student abroad has dramatically changed to $38.5 \%$ or almost four in ten students leaving returned home. Nonetheless, the dip around 2003 was mostly due to SARS.

The trend of returnees according to their sponsorship status is illustrated in Figure 5. Similar to Figure 1, financial support is provided by the government, by organizations or assumed by the individuals. Overall, from 2003 to 2008 the total number of returnees increased by almost 50,000. The number of self-financed students, in particular, grew by 44,000 within these six years. Figure 5 also shows that the number of students who were financed by the government increased.

Returning students and scholars play a leading role in fostering new high-tech start-ups and upgrading educational institutions (Naughton, 2007, p. 363). The important contributions of these returnees, often called haiguipai, are observed in almost all relevant societal domains. Returnees are present in leadership positions at educational institutions, research centers, investment banks, insurance agencies, state and private enterprises, law firms etc., and some are even well integrated into the Chinese political arena ( $\mathrm{Li}, 2006)$. Examining the distribution of the overseas educational attainment of Chinese leaders Li (2006) finds that almost 49.2\% were visiting scholars, 32.8\% PhD graduates, 3.3\% post-doctoral fellows, 9.9\% MA/MS graduates and $1.6 \% \mathrm{JD} / \mathrm{MD}, \mathrm{MBA}$ or $\mathrm{BA} / \mathrm{BS}$. In addition, with regards to their respective fields of responsibility, the author finds that roughly $79 \%$ of these returnees were in charge of science and 
technology, education, industrial development, finance, foreign trade and foreign affairs, $6.6 \%$ were in the political scene (organization or political publicity) and $1.6 \%$ in charge of rural development. Furthermore, by classifying these returnees according to their (high-ranking leader) length of study time, the author finds that $73.8 \%$ spent fewer than three years abroad, and $11.4 \%$ stayed more than six years; however, it should be noted that most of these years were spent in intensive study for a doctorate.

Chinese higher educational institutes have made great efforts to attract returnees as well. Their strategic goal is to be on the list of the world's best universities as soon as possible. For example, Tsinghua University and Peking University, the two most prestigious universities in China, allocated $20 \%$ of their annual budget to attract talent, with preference given to those from abroad (Le Bail and Shen, 2008).

\section{China's Academic Presence and Influence in the International Scene}

China's concerted effort to strengthen its international competitiveness was primarily set up in the mid-1990s as "science, technology and education were put at the forefront of development policy" (Dahlman and Aubert, 2001, p. 18). Statistics on China's educational outcomes as well its scholarly output, especially in natural sciences and engineering, are impressive. China has followed a steady upward trend of 'first university degrees ${ }^{8}$ in natural sciences and engineering. Figure 6 depicts the number of university graduates in natural sciences and engineering in China and other selected developed countries from 1998 to 2006. ${ }^{9}$ In 1998 already, China had the largest number of university graduates in natural sciences and engineering from the USA, Japan, South Korea and Germany. These numbers remained stagnant throughout this period for all four developed countries. In the USA, in particular, while the numbers of these graduates was higher than Japan, South Korea and Germany, they hardly changed over this period (from 205,000 in 1998 to 237,000 in 2006). Japan, Germany and South Korea had either below or just above 100,000 graduates per annum in natural sciences and engineering over this period. In sharp contrast, the numbers for China kept increasing, going from 239,000 in 1998 to 807,000 in 2006.

\footnotetext{
${ }^{8}$ A first university degree is the equivalent of the American Bachelor's degree.

${ }^{9}$ The choice of countries is based on the selection made by National Science Board (2010). Data for the first university degree in Natural Sciences and Engineering are not available for other countries in that report.
} 
Since 2002, especially, the number of university graduates in natural sciences and engineering seems to have taken off and keeps rising (National Science Board, 2010, p. O-7).

With regards to $\mathrm{PhD}$ graduates in natural sciences and engineering Figure 7 contains data on those countries (USA, Germany, China, UK, Japan, South Korea, and India) that are considered by the National Science Board (2010) as the leaders of producing doctoral degrees in the field. One finds that China has come a long way since the early 1990s, emerging as a country that is producing a growing number of doctorates at a rapid pace. While the USA has still the sovereignty of and is keeping reins on the production of natural sciences and engineering $\mathrm{PhDs}$ staying above all other countries - China experienced a tenfold increase in its PhDs. While in 1993 the number of awarded doctorates in China was about 1,000, in 2006, it was 21,000. Moreover, since the early 2000s China's PhDs seem to increase at an increasing rate and approaching the USA fast. It is also worth mentioning that other emerging countries, particularly India, have experienced a considerable rise in terms of $\mathrm{PhD}$ graduates in natural sciences and engineering as well (National Science Board, 2010, p. O-7).

Even more important than the number of $\mathrm{PhDs}$ is the scholarly output produced. Looking at the number of refereed journal articles in science and engineering of selected countries ${ }^{10}$ in 1988 and in 2008, Figure 8 shows that China stands out. In 1988, China produced about 5,000 S\&E journal articles, twenty years later that number has more than twelvefold (61,000 in 2008). The later outnumbered the number of S\&E journal articles produced by Japan $(48,000)$, and even the Asia-8 (57,000). According to the latest National Science Board report (2010), researchers in the EU and the USA have long dominated the world's journal article production. However, their combined world share of published science and engineering articles steadily decreased from $69 \%$ in 1995 to $59 \%$ in 2008. On the other hand, both Asia's-10 and Asia's-8 ${ }^{11}$ scholarly output in science and engineering articles has been increasing (National Science Board, 2010, p. O-9). ${ }^{12}$

\footnotetext{
${ }^{10}$ The geographical distribution of the authors indicates the size of a country's or region's research enterprise and its ability to produce research results that can pass peer review (Science and Engineering Indicators, 2010, p. 0-9). The National Science Board (2010, p. 0-10) has "articles classified by year of publication and assigned to region/country on basis of authors' institutional address(es). For articles with collaborating institutions from multiple countries/economies, each country/economy receives fractional credit on basis of proportion of its participating institutions."

${ }^{11}$ Asia-8 includes India, Indonesia, Malaysia, Philippines, Singapore, South Korea, Taiwan, and Thailand. Asia-10 includes China, Japan and Asia-8 (http://www.nsf.gov/statistics/seind10/c0/c0g.htm).
} 
Lastly, we examine the distribution of publications by discipline for some selected countries. In a sense this could reflect where a country's research priorities lie; for instance whether they lie in natural sciences, engineering, medical sciences or others. Figure 9 illustrates this distribution in 2007. Compared to other countries in Figure 9, the USA exhibits a more balanced distribution of journal articles among the fields of natural sciences, medical sciences and biological sciences. However, the USA's publications in engineering and the social or behavioral sciences are four times lower. In contrast, China's distribution is completely different. Its scholarly output lies predominantly in the natural sciences with $59 \%$ of the scientific papers published by Chinese scholars. China's largest share in natural sciences publication might be justified by the country's need to expand its chemical industry (National Science Board, 2010, p. O-9). Engineering is the next field with $17 \%$ of the publications, followed closely by biological sciences with $15 \%$. Medical sciences claim only $8 \%$ of the publications and last are the social and behavioral sciences with only $1 \%$.

With the exception of South Africa, all other countries in Figure 9 show that the larger number of publications comes from the natural sciences: India (52\%), Singapore (43\%), Japan (41\%), France (44\%) and Germany (38\%). Germany's next mostly published fields are medical sciences (27\%) and biological sciences (23\%). Engineering occupies $8 \%$ of the publications and social and behavioral sciences rank last with $5 \%$.

Investments in Research and Development (R\&D) go hand in hand with a country's research priorities. Spending in $R \& D$ is, undoubtedly, of paramount importance for any country's development and competitiveness. Figure 10 shows R\&D expenditures as percentage of GDP in 1996 and 2007 for countries and economic areas selected by the National Science Board (2010). Asian countries, such as South Korea and Japan devoted a large share of their economic output to $R \& D$. China, compared with other economies, spends less on $R \& D$. Nonetheless, China's R\&D/GDP ratio more than doubled, from $0.6 \%$ in 1996 to $1.5 \%$ in 2007. As mentioned by the National Science Board (2010), "the gap in China's R\&D/GDP ratio relative to those of developed economies suggests that China's R\&D volume can continue to grow rapidly" (p. 0-4). 


\section{IV. 'Luring Brains In’: Can China Reach Human Capital Supremacy?}

At the signing ceremony on scientific and the cultural exchange between the USA and China in 1978, President Jimmy Carter, following Premier Deng Xiaoping’s remark, said: “Our aim is to make this kind of exchange between our countries no longer the exception but the norm; no longer a matter of headlines and the historians, but a routine part of the everyday life of both Chinese and American people” (as cited in Li, 2010 ${ }^{13}$ ). More than thirty years later, China's booming economy and relatively stable political and social environment have attracted more and more international students to the country.

Official data from the MoE reveal that the overall number of international students in China grew steadily in the last decade, rising from about 50,000 students in 2000 to almost 200,000 in 2007. According to the MoE, 195,503 international students from 188 countries and regions went to study in China; they were distributed among 544 Chinese higher education and research institutes in 2007. The majority of them, 141,689, or 72.5\%, were from Asia, especially from South Korea and Japan. European students were in second place with 26,339 or 13.5\% of the international students in China; they mostly were from the UK, France and Germany. Next were American students (19,673 or 10.1\%), followed by Africans (5,915 or 3\%) and people from Oceania $(1,887$ or $1 \%)$.

Figure 11 is produced by plotting these numbers over time (from 2000 to 2007) as well as by country of origin; the year 2000 is used as the reference year. The number of European and African students in China has quadrupled in seven years. We observe a similar pattern for the Asian and American students, albeit their numbers only tripled; the number of students from Oceania over the same time period doubled. Figure 11 shows that by 2007, there was a serious foreign students presence in China. It is interesting that the SARS pandemic in 2003 decreased the number of students from Europe and the Americas but not those from Oceania and Africa.

Another interesting aspect about the international students in China is their sponsorship type. Figure 12 displays the flows of the international students to China over the last decade by their financial sponsorship status, with 2000 as the reference year. They are categorized as students who are self-financed and those who are financially supported through a scholarship.

\footnotetext{
${ }^{13} \mathrm{Li}$, Cheng’s (2010) comment during a panel discussion “Chinese foreign-educated returnees: Shaping China’s future,” The Brookings Institution, Washington, DC.
} 
Note that self-financed or self-supported status means that these students do not receive support neither from the Chinese government nor from any other Chinese organizations. It includes, however, students who have a scholarship from their home country government or other non Chinese foundations and organizations.

Figure 12 clearly shows that the self-financed students have been gradually playing a dominant role. It also expresses a growing demand for Chinese culture, language and know-how by other countries. Aside from the dip in 2003 - probably mostly related to the SARS epidemic the number of self-financed foreign students increased dramatically over the period of 2000 to 2007. The scholarship-supported status of foreign students in China indicates students who receive scholarships provided by the Chinese government, such as the Chinese government scholarship, the Great Wall Scholarship, the Excellent Student Scholarship, the HSK Winner Scholarship, the short-term program for foreign teachers of Chinese and the Chinese culture research program (MoE, n.d.). Interestingly, the number of scholarship-supported foreign students doubled between 2000 and 2008, indicating a conscious effort to lure and support foreign students wanting to study in China.

Most foreign students in China enroll in non-degree programs, such as studying Chinese language and culture, or in short-term programs of less than six months. In 2007 there were 127,290 such non-degree students, accounting for $65.1 \%$ of the entire international student body in China. Undergraduates came second with $29.3 \%$ of the entire international student body. Note that the number of Master's $(7,628)$ and $\operatorname{PhD}(3,218)$ students was relatively small compared to other student groups, representing 3.9\% and 1.6\%, respectively. Nonetheless, as shown in Figure 13, the number of international students following academic fields - whether they are at the graduate level (Master's and $\mathrm{PhD}$ ) or in non-degree programs - has clearly more than tripled over the past eight years (with the year 2000 as the reference year). Undergraduates, in particular, experienced an almost six-fold increase over the same reference period, and their numbers keep increasing. This indicates that the world is expressing a serious interest in China.

Figure 14 illustrates how international students in China distribute across disciplines in 2007. The vast majority of them go into liberal arts that include Chinese language and culture studies. With 135,477 enrolled students, this seems to be the favorite and most popular discipline. The next most attractive discipline is studies in Chinese and Western medicine with 25,573 international students. Economics with 8,804 and engineering with 6,785 international 
students follow in the enrolment of international students (2008 China Education Yearbook). We conjecture that the relatively high number of international students majoring in medicine in China might be due to the reputed Chinese traditional medicine, i.e., acupuncture practices.

One question that concerns policymakers is how to improve the quality of international education in China and attract more international students. In the Action Plan of 2005 the MoE clearly stated its aim to "adopt a strategy of creating 'renowned brand names' for selected institutions and academic fields and adhere to the principles of 'expanding the scale, raising the level, ensuring the quality, and managing according to established norms and standards"” (Ministry of Education Action Plan, 2005, p. 29).

\section{Conclusions}

In this paper we examined China's lesser known but highly important feature; human capital. Starting with the opening-up reform of 1978 - a landmark for the Chinese modern higher education system - we dissected the available statistics with an emphasis on the past decade. China has achieved important milestones in human capital, working painstakingly and following a steady course. In particular, our study shows that: (i) the number of students enrolled in Chinese higher education institutions has increased dramatically; (ii) more and more Chinese students seek higher education abroad (and are encouraged and supported by the government); (iii) China is producing serious scholars and a tremendous amount of scholarly output; and (iv) international students have started to show a steadily growing interest in receiving education in China.

Specifically, we documented an ever increasing trend of Chinese students going abroad. According to the Ministry of Education statistics, the number of Chinese overseas students has reached about 1.4 million in total by 2008. While many students have returned, many more remain abroad after graduating. Some observers think that China may soon face a brain drain problem. Being aware of the issue, astute Chinese officials have been following a steady course to bring their expatriates back to China by creating a welcoming environment and favorable conditions for them to flourish. Regarding those who choose to stay abroad, China's attitude is to 
befriend them and keep them happy so that the ethnic network stays alive and can be used in the future.

Today, China aims at providing high-quality education, comparable to international universities in Europe and the USA, and produces more university degrees in natural sciences and engineering than any other country. If "science is the ultimate revolution," as Premier Wen (2008) said, then China is 'revolving' fast: (i) it produces an exorbitant amount of doctoral degrees in science and engineering, reaching the level of the USA; (ii) it has the highest annual growth rate of published refereed papers in science and engineering by far; and (iii) it produces the highest percent of scholarly output in the natural sciences with 59\% of the scientific papers published by Chinese scholars. This is more than double the corresponding percent in the USA (27\%), a country that has been long considered the global leader. China is also spending, on average, more on research and development than any other major developed economy in the West. All these facts render China a country that has to be taken seriously in the international academic community.

Lastly, we presented evidence of the Chinese government making great efforts to attract international students from other parts of the world to go to China for their education and of the rest of the world expressing a serious interest in China, ranging from learning about the language and culture to Chinese acupuncture or studying other fields. This is manifested by the increasing number of international students studying in China.

The evidence-based analysis presented in this paper suggests that China has already established itself as a global player in the international market for higher education. It has build up internal capacities successfully and seems to attempt to take over the strategy of the USA to internationalize and to attract talent from the world instead of chosing the more inward-looking and hesitant European model. Globalization is at the core of China's human capital strategy. On this way, it is not counterproductive to intensify the outflow of Chinese students to the USA, given the efforts to stabilize the ethnic network to the own diaspora and to encourage return migration. The strong presence of China in the education of students from Asia and the Third World is also in line with its policy to strengthen its access to the natural resources in those countries and to ensure close future economic collaborations. Hence, China will challenge the American role model and may become an educator and employer for the talented of the Third World. 
It is said that whoever wins the battle over talents will be the victor of the $21^{\text {st }}$ century. All countries advocate the need for skilled immigrants. China has undoubtedly emerged as one of the largest economies in the world and has shown considerable global power, which begs the question of whether China is satisfied with only being the world's cheap manufacturer. If not, can China turn its labor intensive economy into a knowledge-based one and win the global tugof-war for talents? 


\section{References}

Bergsten, C. F., C. Freeman, N. R. Lardy and D. J. Mitchell (2009). China's Rise: Challenges and Opportunities. Washington, DC: Peter G. Peterson Institute for International Economics and Center for Strategic and International Studies.

Böhm, A., M. Follari, A. Hewett, S. Jones, N. Kemp, D. Meares, D. Pearce and K. Van Cauter (2003). "Vision 2020: Forecasting International Student Mobility: A UK Perspective," British Council. http://www.britishcouncil.org/eumd___vision_2020.pdf, accessed June 22, 2010.

Brandenburg, U. and J. Zhu (2007). "Higher Education in China in the Light of Massification and Demographic Change: Lessons to be Learned for Germany.” CHE Working Paper No. 97, Gütersloh.

China Scholarship Council (November 9, 2007). Regulation of State-sponsored Study Abroad Program (Trial Implementation). http://www.csc.edu.cn/Chuguo/46268dabb46a4ae1a7b9 ca215142f5d1.shtml (in Chinese), accessed June 29, 2010.

China Scholarship Council. http://en.csc.edu.cn/Chuguo/, accessed June 17, 2010.

Constant, A. F., B. N. Tien and J. Meng (2010). "Can China Win the Tug-of-War for Talents.” DIWDCSynopsis, No. 2.

Dahlman, C. J. and J.-E. Aubert (2001). "China and the Knowledge Economy: Seizing the 21st Century.” WBI Development Studies, Washington, DC: The World Bank.

Frazier, M. W. (2010). "China's Domestic Policy Fragmentation and 'Grand' Strategy in Global Politics.” Asia Policy, 10 (July 2010): 87-101.

Halper, S. (2010). "Beijing's Coalition of the Willing: For the West, Failed States are a Problem. For China, They’re an Opportunity.” Foreign Policy, July/August 2010: 100-102.

Heckman, J. J. (2003). “China’s Investment in Human Capital.” Economic Development and Cultural Change, 51 (4): 795-804.

Heckman, J. J. and X. Li (2004). "Selection Bias, Comparative Advantage and Heterogeneous Returns to Education: Evidence from China in 2000.” Pacific Economic Review, 9 (3): 155171.

Institute of International Education. Open Doors Data Tables. http://www.iie.org/en/ Researchand-Publications/Open-Doors, accessed June 14, 2010.

Le Bail, H. and W. Shen (2008). "The Return of the "Brains" to China: What are the Social, Economic, and Political Impacts?” Asie. Vision 11. Paris: French Institute of International Relations (IFRI).

Li, C. (2006). "Foreign-educated Returnees in the People's Republic of China: Increasing Political Influence with Limited Official Power.” Journal of International Migration and Integration, 7 (4): 493-516.

Li, S. and C. Xing (May 2010). "China’s Higher Education Expansion and its Labor Market Consequences.” IZA Discussion Paper No. 4974, Bonn, DE.

Meng, X. and B. Gregory (January 2007) "Exploring the Impact of Interrupted Education on Earnings: The Educational Cost of the Chinese Cultural Revolution." IZA Discussion Paper No. 2548, Bonn, DE.

Ministry of Education Action Plan (2005). 2003-2007 Action Plan for Invigorating Education. Beijing. Ministry of Education of the People's Republic of China. 
Ministry of Education of the People's Republic of China (MoE) (2001-2008). China Education Yearbook. Beijing, China: People's Education Press. Under: http://www.moe.gov.cn/ edoas/website18/top_nianjian.jsp (in Chinese), accessed June 10, 2010.

Ministry of Education of the People's Republic of China (MoE) (n.d.). Work Related to Students and Scholars Studying Abroad. http://www.moe.edu.cn/english/international_ 2.htm (in Chinese), accessed June 10, 2010.

Mullins, R. (2005). “Test Fever.” In China Today. http://www.chinatoday.com.cn/English/e2005 /e200506/p34.htm, accessed June 23, 2010.

National Bureau of Statistics of China (2009). China Statistical Yearbook 2009. Beijing: China Statistics Press. http://www.stats.gov.cn/tjsj/ndsj/2009/indexeh.htm, accessed June 15, 2010.

National Science Board (2010). Science and Engineering Indicators 2010. Arlington, VA: National Science Foundation.

Naughton, B. (2007). The Chinese Economy: Transitions and Growth. Cambridge, MA: MIT Press.

NesoChina (2008). Chinese Government Scholarship for Outstanding Self-financed Students Studying Abroad. http://www.nesochina.org/chinese-students/information-inenglish/schola rships/governmental-scholarships/chinese-government-scholarship-for-outstanding-self-fin anced-students-studying-abroad, accessed June 10, 2010.

Ouyang, K. (2004). “Higher Education Reform in China Today.” Policy Futures in Education, 2 (1): $141-149$.

UNESCO Institute for Statistics. Online Education Database. http://stats.uis.unesco.org/une sco/TableViewer/document.aspx?ReportId=143\&IF_Language=eng, accessed June 22, 2010.

Wen, J. (2008). “Science and China’s Modernization.” Science, 322 (5902): 649.

Yao, L. (2004). "The Chinese Overseas Students: An Overview of the Flows Change.” 12th Biennial Conference of the Australian Population Association. Canberra, Australia.

Yao, Y. (2010). "The End of the Beijing Consensus: Can China's Model of Authoritarian Growth Survive?” Foreign Affairs, February 2. http://www.foreignaffairs.com/print /65914?page=show, accessed July 29, 2010.

Zhang, J., P. Liu and L. Yung (2007). "The Cultural Revolution and Returns to Schooling in China: Estimates based on Twins.” Journal of Development Economics, 84 (2): 631-639.

Zhao, L. and J. Zhu (2009). "China Attracting Global Talent: Central and Local Initiatives." China: An International Journal, 7 (2): 323-335. 
Table 1: International Flows of Students at the Tertiary Level - Matrix of the Top 5 Host and Home Countries in 2008

\begin{tabular}{|c|c|c|c|c|c|c|c|}
\hline \multirow[b]{3}{*}{ Home Country } & \multicolumn{6}{|c|}{ Host Country } & \multirow{3}{*}{$\begin{array}{c}\text { Total } \\
\text { number of } \\
\text { native } \\
\text { students } \\
\text { abroad } \\
\end{array}$} \\
\hline & 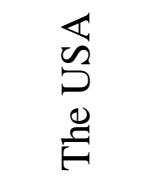 & 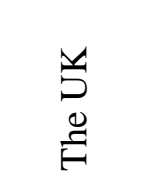 & 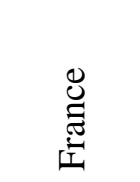 & 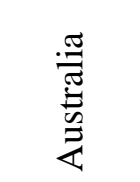 & 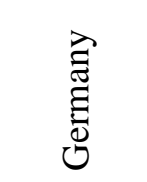 & 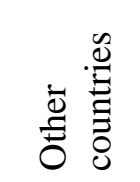 & \\
\hline & 1 & 2 & 3 & 4 & 5 & 6 & \\
\hline 1 China & 110,246 & 45,356 & 20,852 & 57,596 & 21,977 & 163,082 & 419,109 \\
\hline 2 India & 94,664 & 25,901 & 1,038 & 26,520 & 3,257 & 13,700 & 165,080 \\
\hline 3 Republic of Korea & 69,198 & 4,031 & 2,292 & 6,270 & 3,929 & 25,683 & 111,403 \\
\hline 4 Germany & 8,917 & 13,625 & 6,918 & 1,934 & - & 46,857 & 78,251 \\
\hline 5 Japan & 34,010 & 4,465 & 1,908 & 2,974 & 1,858 & 3,623 & 48,838 \\
\hline $\begin{array}{l}6 \text { Other Countries } \\
\text { Total number of } \\
\text { foreign students in } \\
\text { the host country }\end{array}$ & 307,439 & 248,413 & 210,428 & 135,341 & 158,326 & 660,351 & $1,720,298$ \\
\hline
\end{tabular}

Note: Tertiary education refers to ISCED 5 and 6.

Source: UNESCO Online Education Database, http://stats.uis.unesco.org; own presentation.

Table 2: Main Official Programs to Fund Chinese Returnees

\begin{tabular}{|c|c|c|c|}
\hline Program Name & $\begin{array}{c}\text { Starting } \\
\text { Year }\end{array}$ & Targeted Group & Incentives \\
\hline $\begin{array}{l}\text { The Fund for Returnees } \\
\text { to Launch Science and } \\
\text { Technology Researches }\end{array}$ & 1990 & $\begin{array}{l}\text { Returnees with doctoral degree } \\
\text { who work at education and } \\
\text { research institutes }\end{array}$ & $\begin{array}{l}\text { Provide funds for purchasing } \\
\text { equipments and books, doing on- } \\
\text { site research, and attending } \\
\text { conferences }\end{array}$ \\
\hline $\begin{array}{l}\text { Program for Training } \\
\text { Talents toward the } 21^{\text {st }} \\
\text { Century }\end{array}$ & 1993 & $\begin{array}{l}\text { Outstanding young teachers } \\
\text { returning from overseas }\end{array}$ & $\begin{array}{l}\text { Provide } 200,000 \text { to } 300,000 \text { yuan } \\
\text { annually for doing research in } \\
\text { major topics }\end{array}$ \\
\hline $\begin{array}{l}\text { The Chunhui Program } \\
\text { (literally, Spring Bud) }\end{array}$ & 1996 & $\begin{array}{l}\text { Returnees with doctoral degree } \\
\text { and outstanding achievements } \\
\text { in their fields }\end{array}$ & $\begin{array}{l}\text { Cover traveling expenditure to } \\
\text { attend conferences and academic } \\
\text { exchange programs }\end{array}$ \\
\hline $\begin{array}{l}\text { Changjiang }^{* *} \text { Scholar } \\
\text { Incentive Program }\end{array}$ & 1998 & $\begin{array}{l}\text { Young and middle-aged } \\
\text { leading Chinese scholars who } \\
\text { have experience studying } \\
\text { abroad and are invited by HEIs } \\
\text { as visiting professors }\end{array}$ & $\begin{array}{l}\text { The program provides } 100,000 \\
\text { yuan annual incentives, and the } \\
\text { HEIs offer the salary, insurance } \\
\text { and other social welfares during } \\
\text { the visit. }\end{array}$ \\
\hline
\end{tabular}


Table 2: Main Official Programs to Fund Chinese Returnees

\begin{tabular}{lcll}
\hline Program Name & $\begin{array}{c}\text { Starting } \\
\text { Year }\end{array}$ & Targeted Group & Incentives \\
\hline $\begin{array}{l}\text { Program of Academic } \\
\text { Short-return for }\end{array}$ & 2001 & $\begin{array}{l}\text { Outstanding Chinese scholars } \\
\text { who come back to China in } \\
\text { Scholars and Research }\end{array}$ & $\begin{array}{l}\text { The Ministry of Education covers } \\
\text { traveling expenditures, and HEIs } \\
\text { Overseas }\end{array}$ \\
& & $\begin{array}{l}\text { do research in 28 key Chinese } \\
\text { HEIs }\end{array}$ & $\begin{array}{l}\text { pay salaries, provide } \\
\text { accommodation and health } \\
\text { insurance }\end{array}$ \\
\hline
\end{tabular}

Note: ${ }^{*}$ For detailed information, refer to http://www.moe.gov.cn/edoas/website18/level3.jsp?tablename=12632606 67176395\&infoid $=1263277716024458$ (in Chinese).

${ }^{* *}$ It is also called the 'Yangtze River,' literally translated as the 'Long River.' It is the longest river in China and Asia and the third longest one in the world.

${ }^{* * *}$ The list of 28 key Chinese Higher Education Institutes (HEI) is available at http://www.moe.gov.cn/edoas/ website18/level3.jsp?tablename=1305\&infoid=12200 (in Chinese).

Source: Ministry of Education of the People's Republic of China, http://www.moe.edu.cn/english/ international_2.htm.

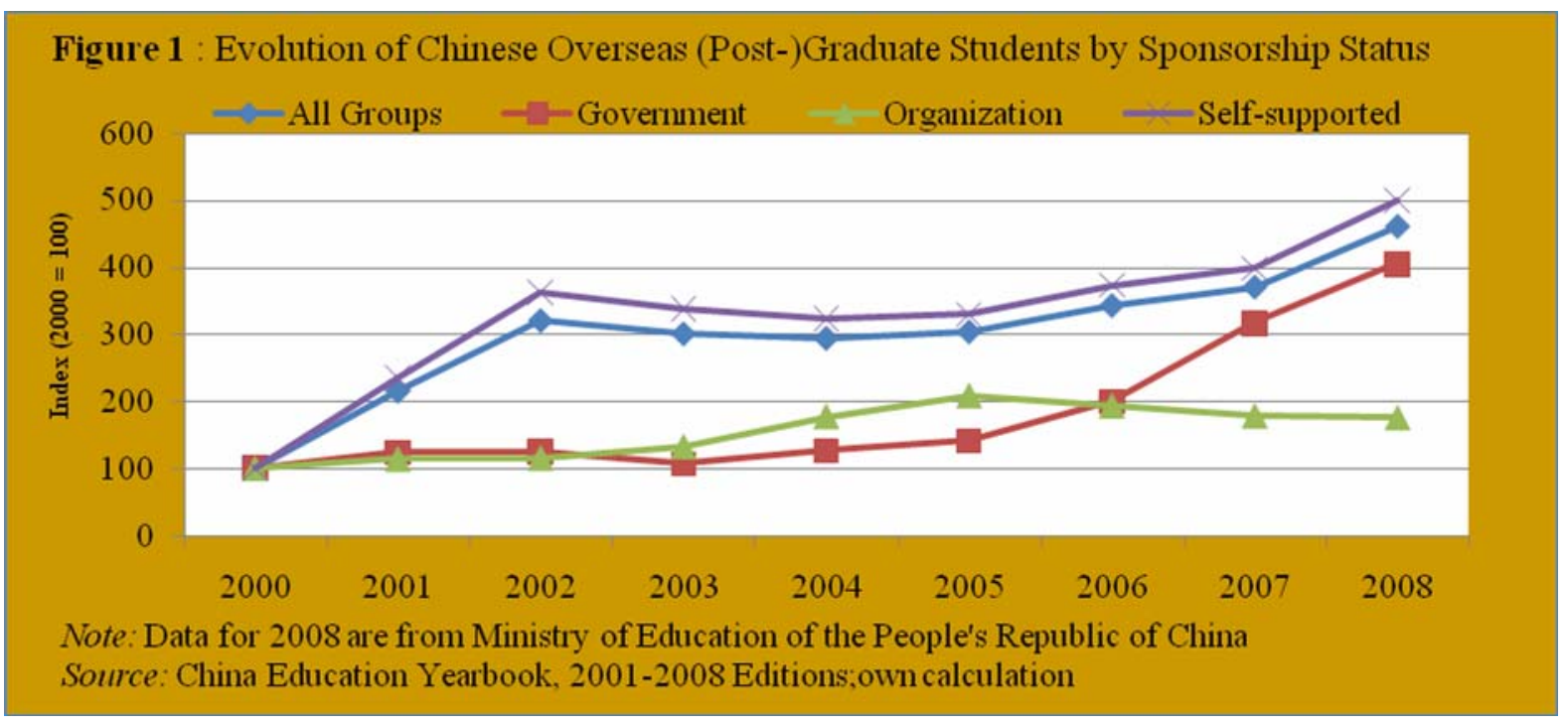


Figure 2: Flows of Chinese Students at the Tertiary Level to some Selected Host Countries: 1999-2008

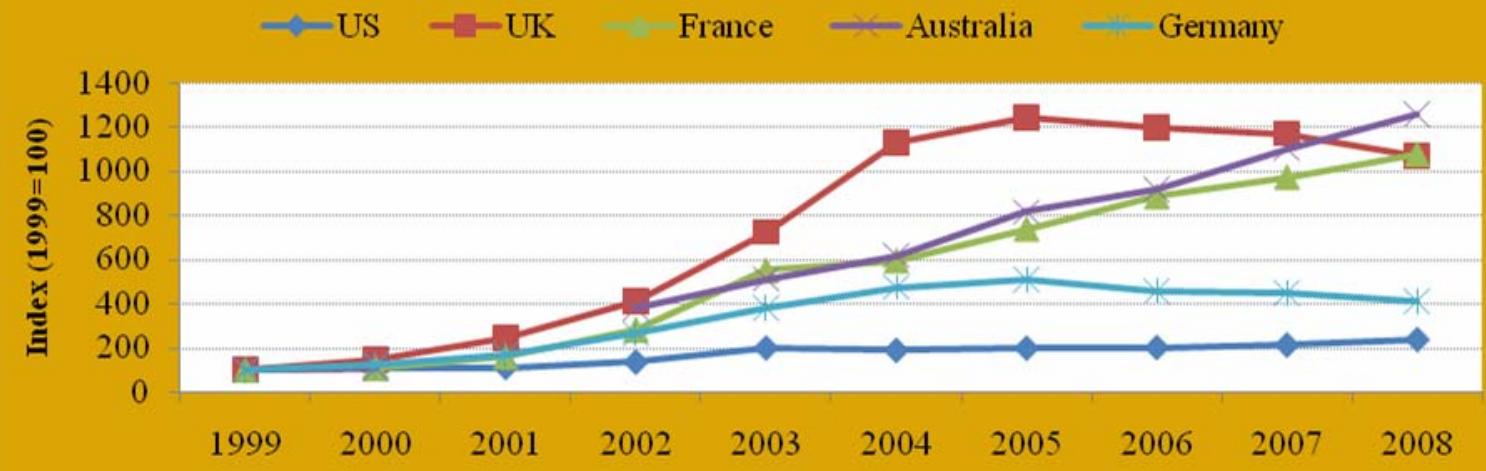

Note: Data for Australia in 2001 were not available in the UNESCO database Source: UNESCO education online database; own presentation

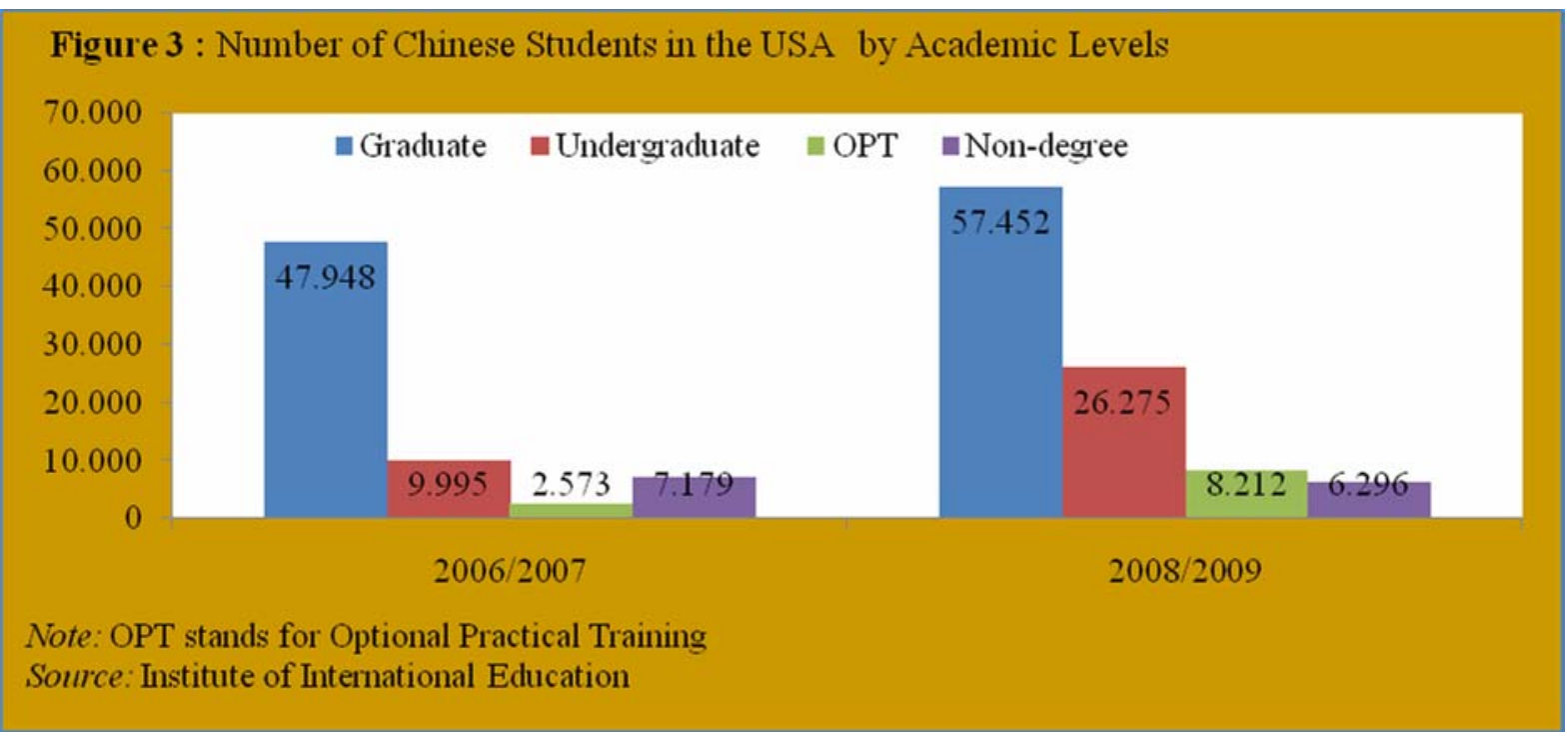


Figure 4: Evolution of GDP per Capita and Returnees-Students Going Abroad Ratio, 1999-2008

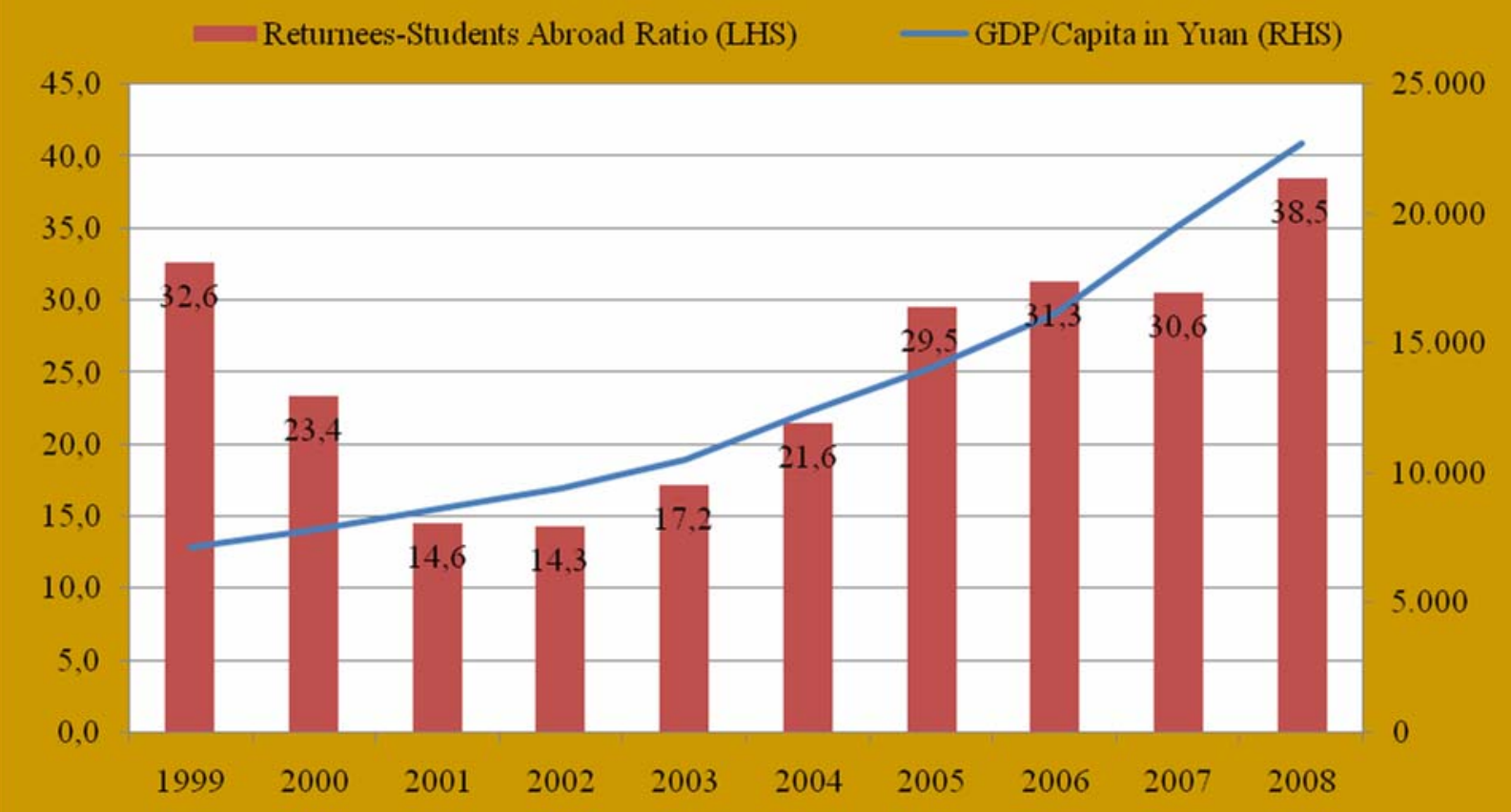

Source: China Statistical Yearbook 2009, 20-8; World Bank (for GDP per Capita); own presentation

Figure 5: Number of Overseas Students Back to China by Sponsorship Status: 2003-2008

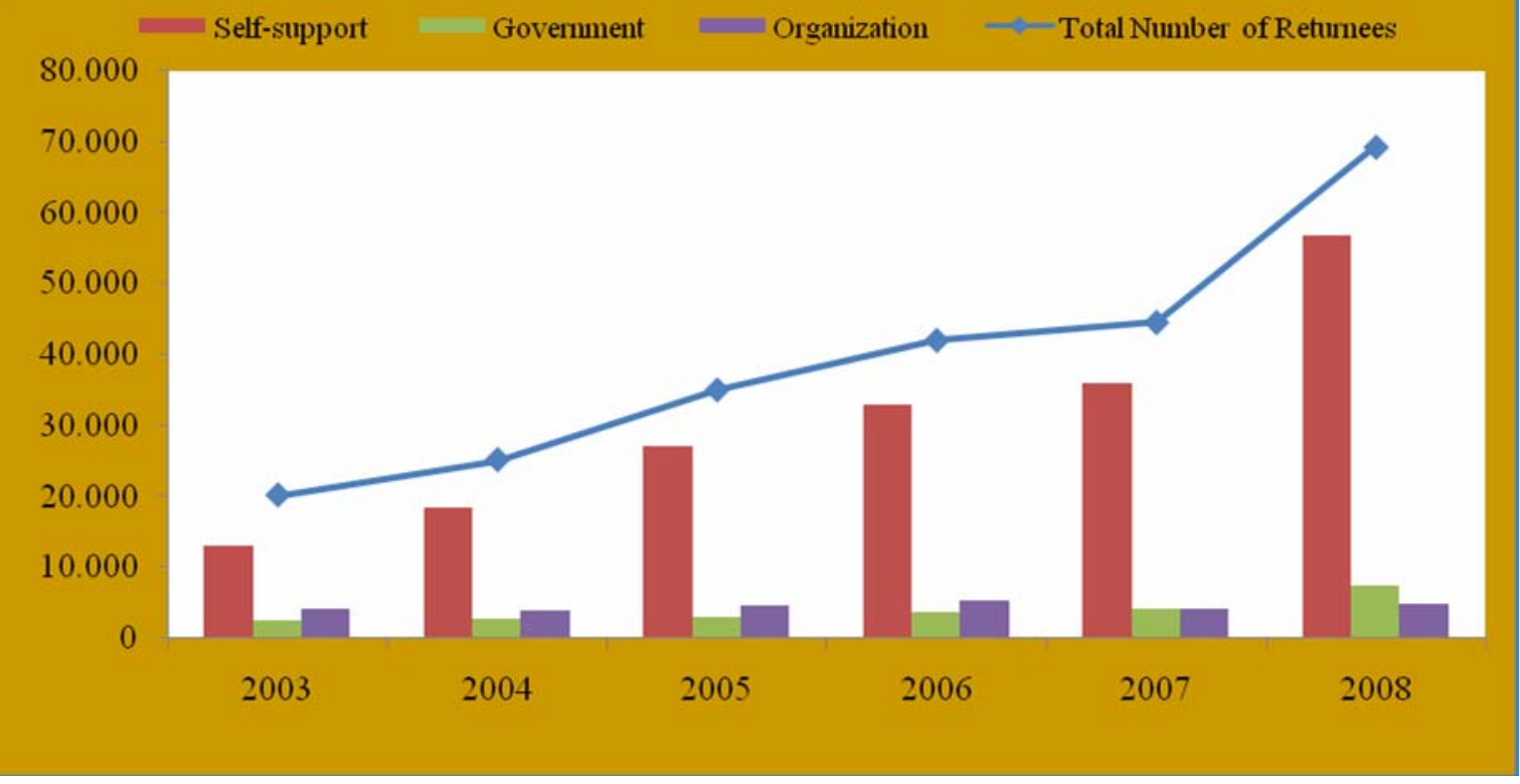


Figure 6: First University Degrees in Natural Sciences and Engineering, Selected Countries: 1998-2006

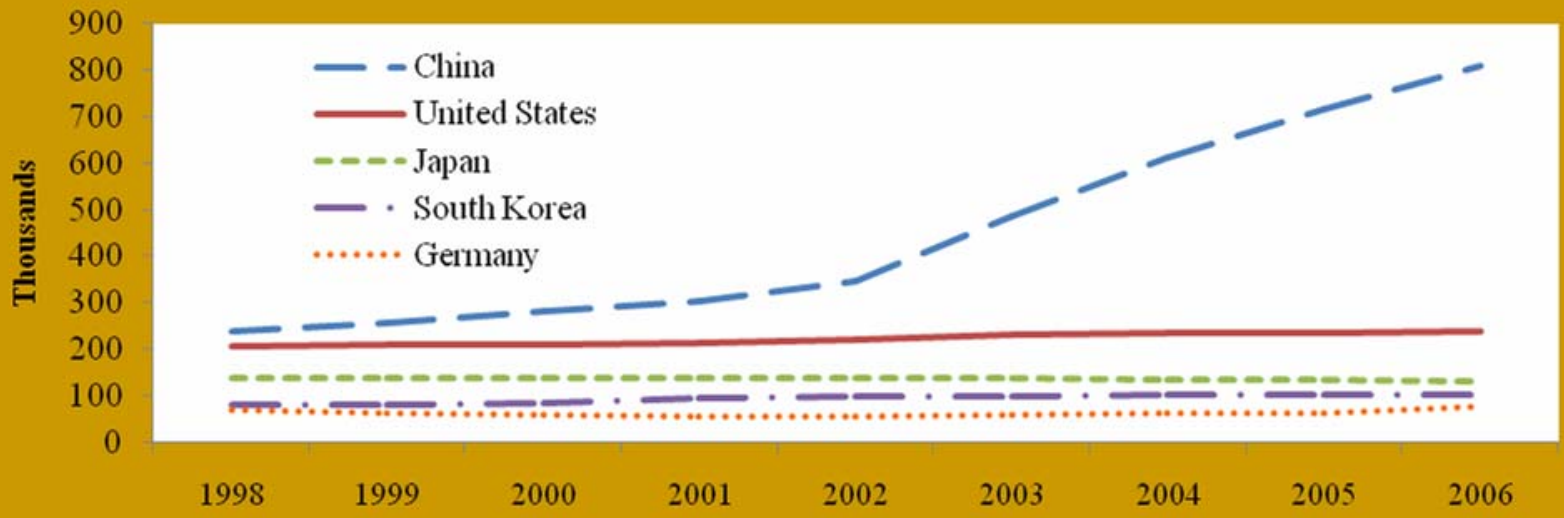

Source: Adopted from National Science Foundation, Science and Engineering Indicators 2010

Figure 7: Doctoral Degrees in Natural Sciences and Engineering, Selected Countries: 1993-2007

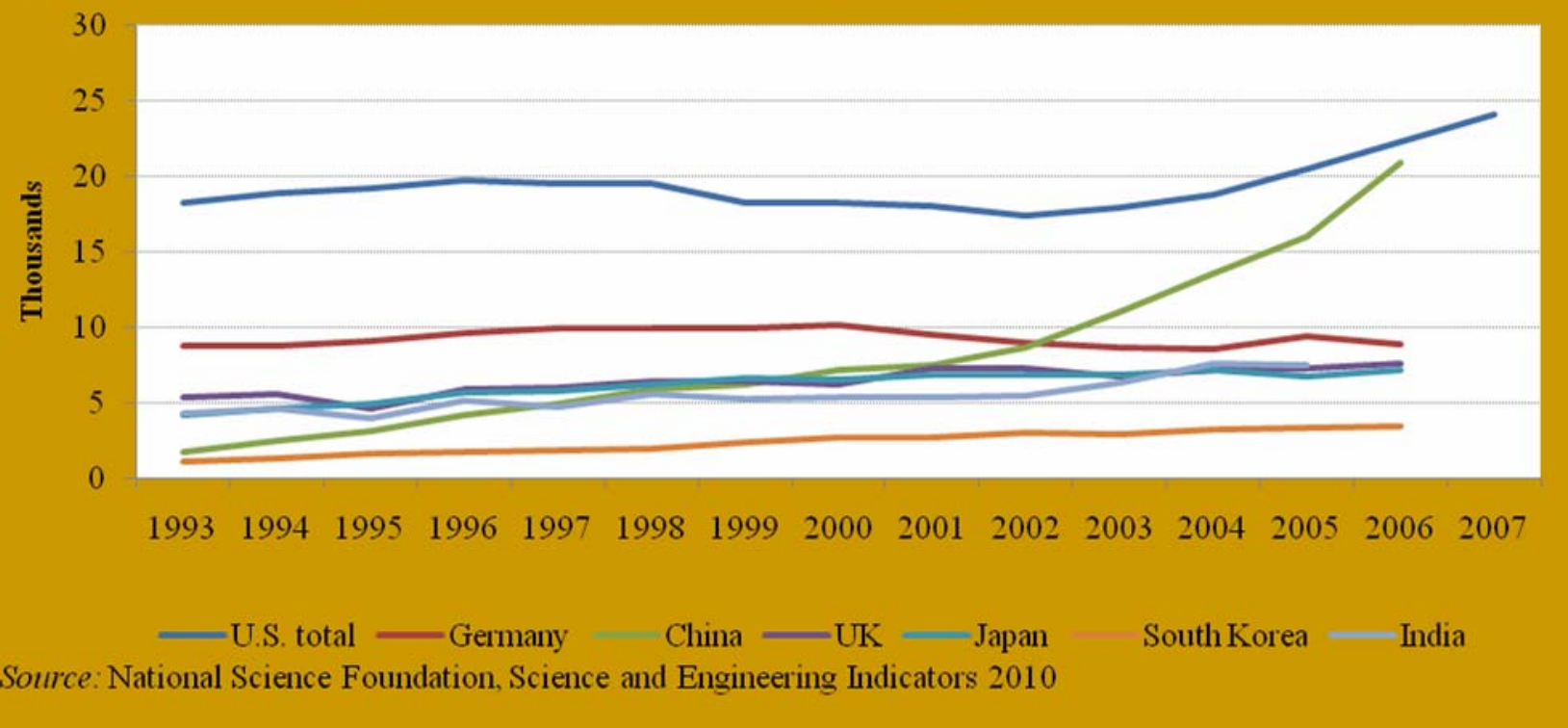




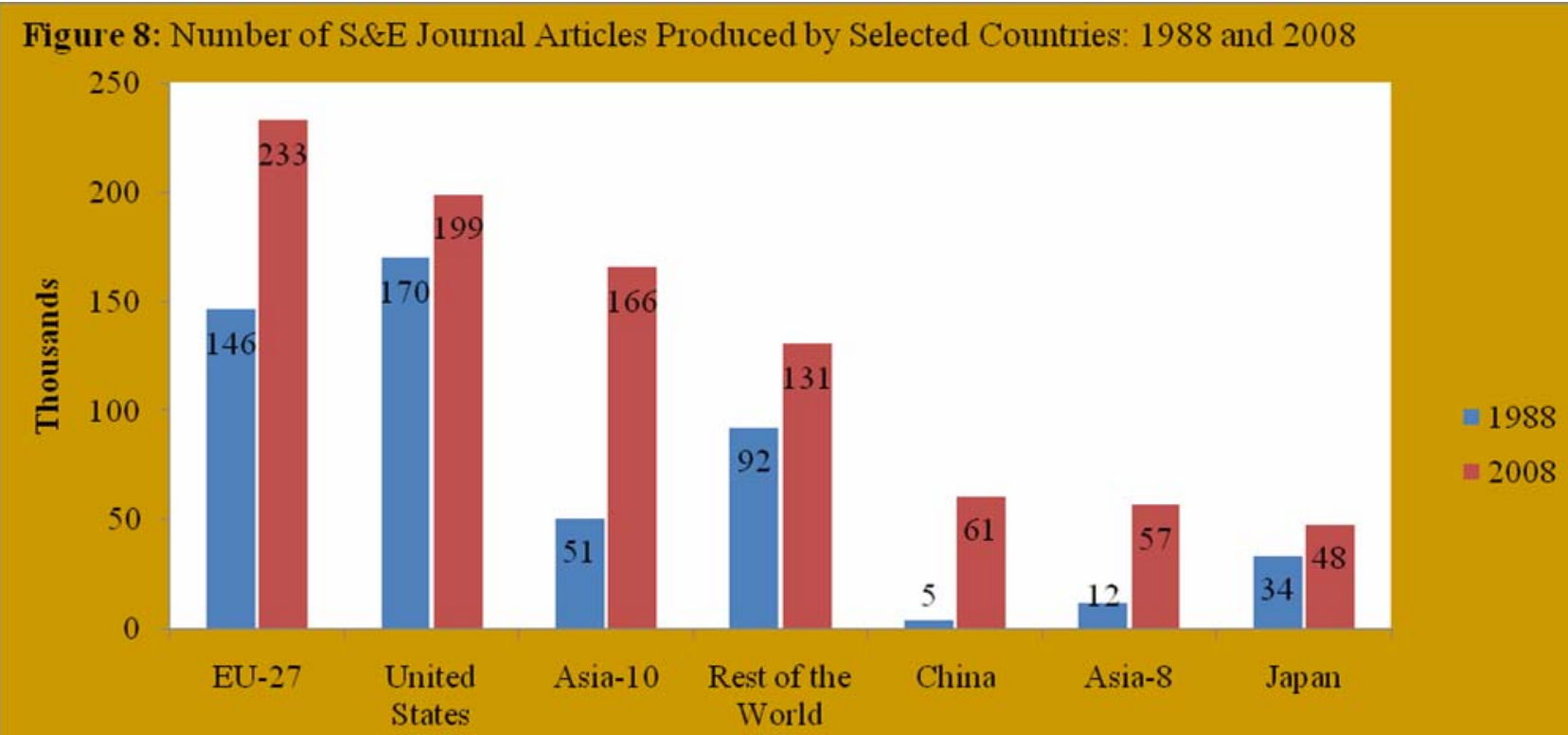

Note: Asia-8: Includes India, Indonesia, Malay sia, Philippines, Singapore, South Korea, Taiwan, and Thailand Asia-10: Includes China, Japan, and Asia-8

Source: National Science Foundation, Science and Engineering Indicators 2010; own presentation

Figure 9: Shares of Research Articles by Field of Study for Selected Countries: 2007

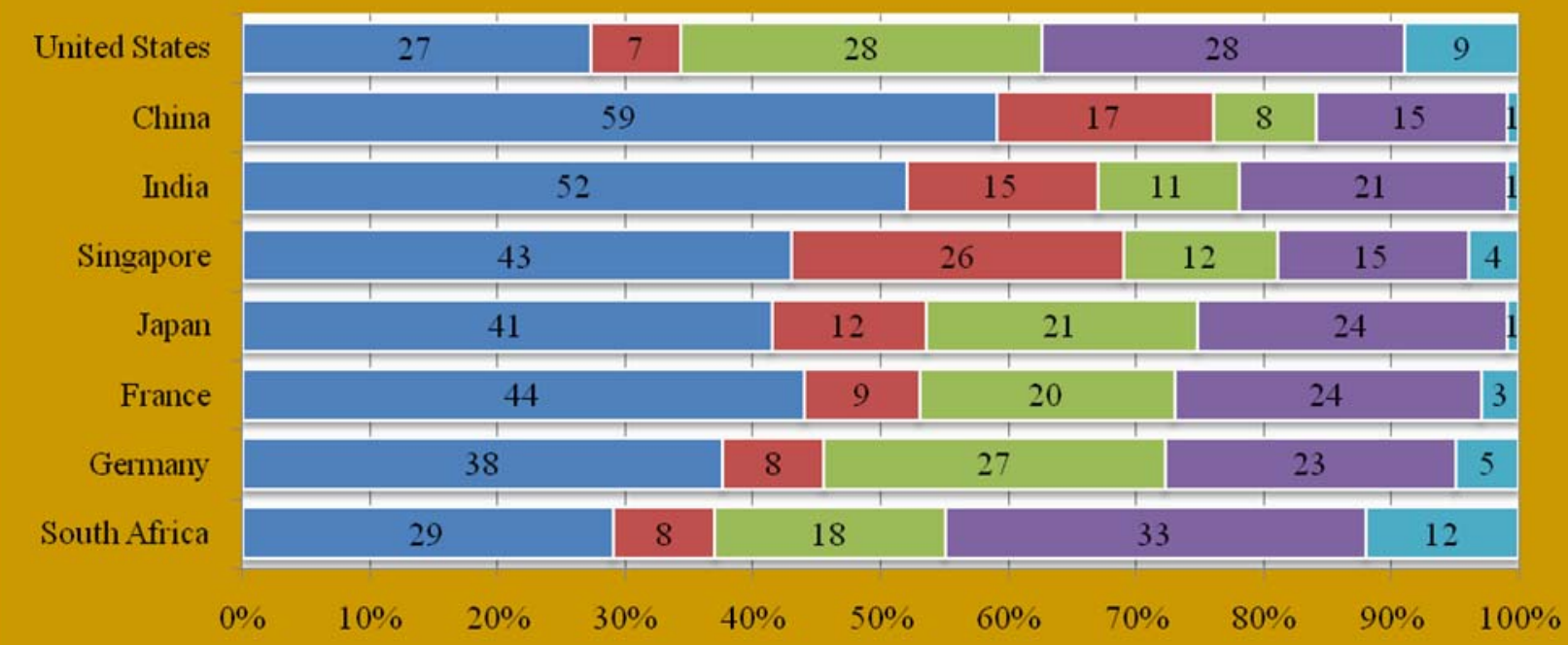

$\square$ Natural sciences $\quad \square$ Engineering $\square$ Medical sciences $\square$ Biological sciences $\square$ Social/behavioral Source: Adopted from National Science Foundation, Science and Engineering Indicators 2010 sciences 
Figure 10: R\&D Expenditures as Share of Economic Output of Selected Economies: 1996 and 2007

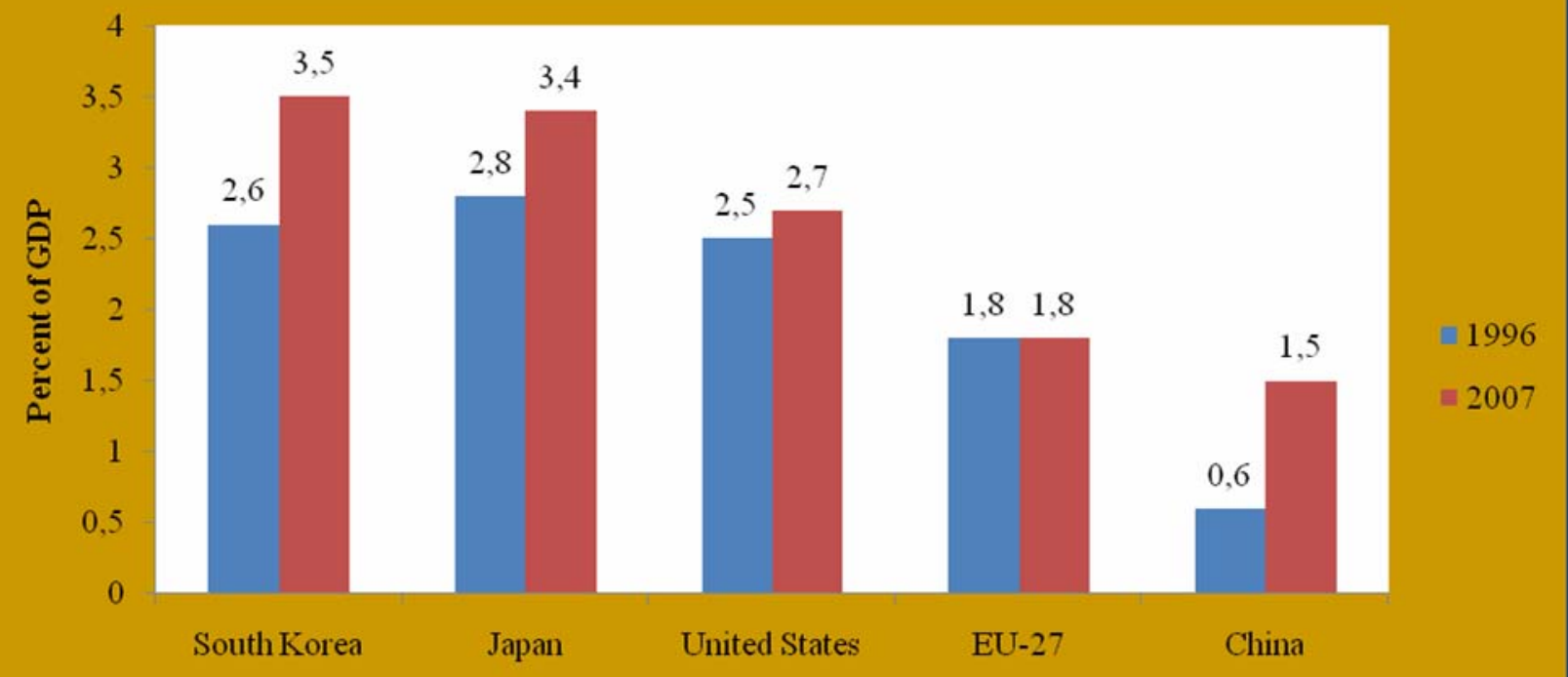

Source: National Science Foundation, Science and Engineering Indicators 2010; own presentation

Figure 11: Evolution of International Students in China by Place of Origin: 2000-2007

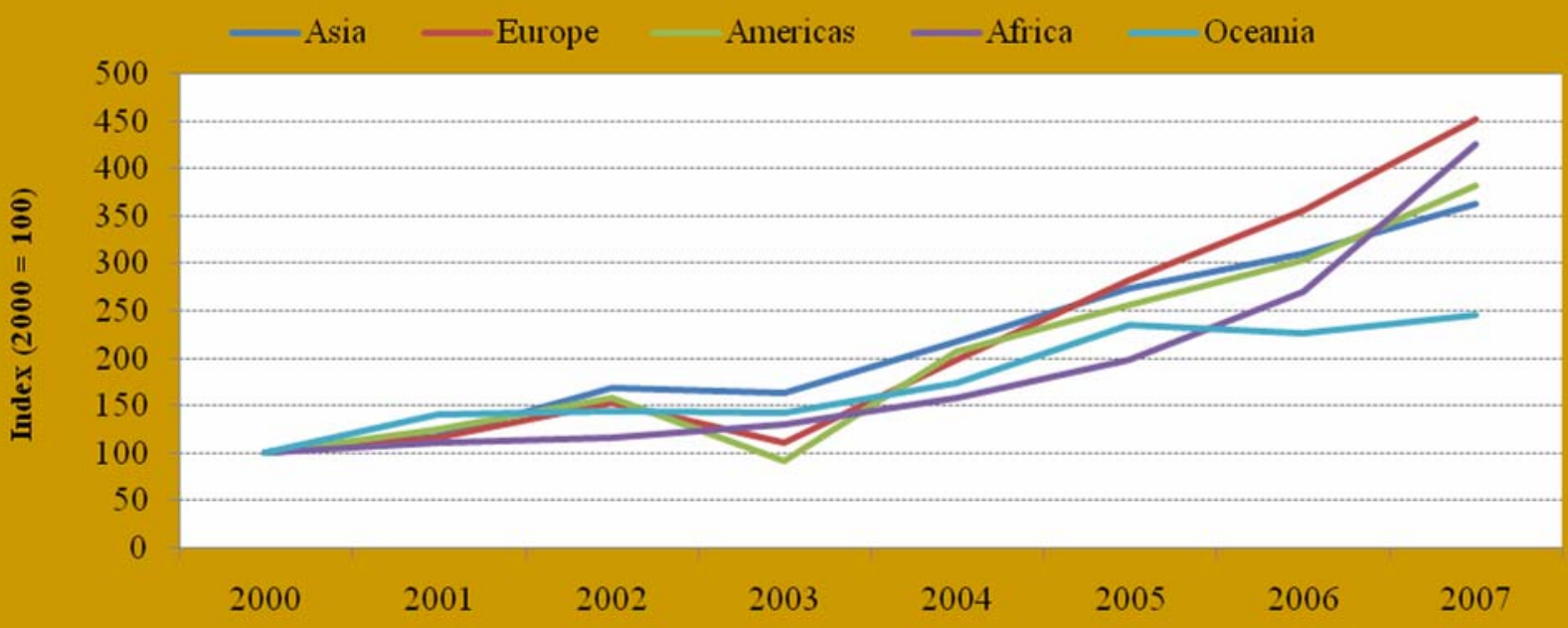

Source: China Education Yearbook, 2001-2008 Editions; own calculation 
Figure 12: Flows of International Students to China by Sponsorship Status: 2000-2007

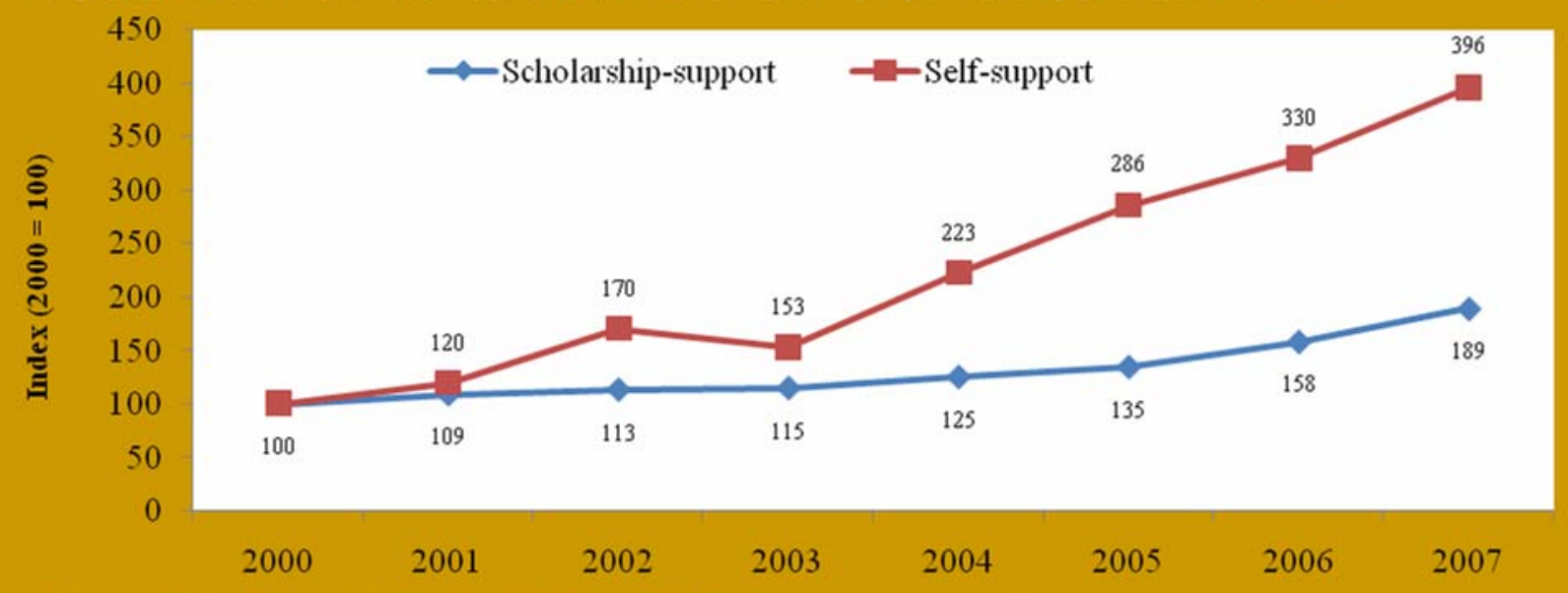

Source: China Education Yearbook, 2001-2008 Editions; own presentation

Figure 13: Flows of International Students to China by Academic Level: 2000-2007

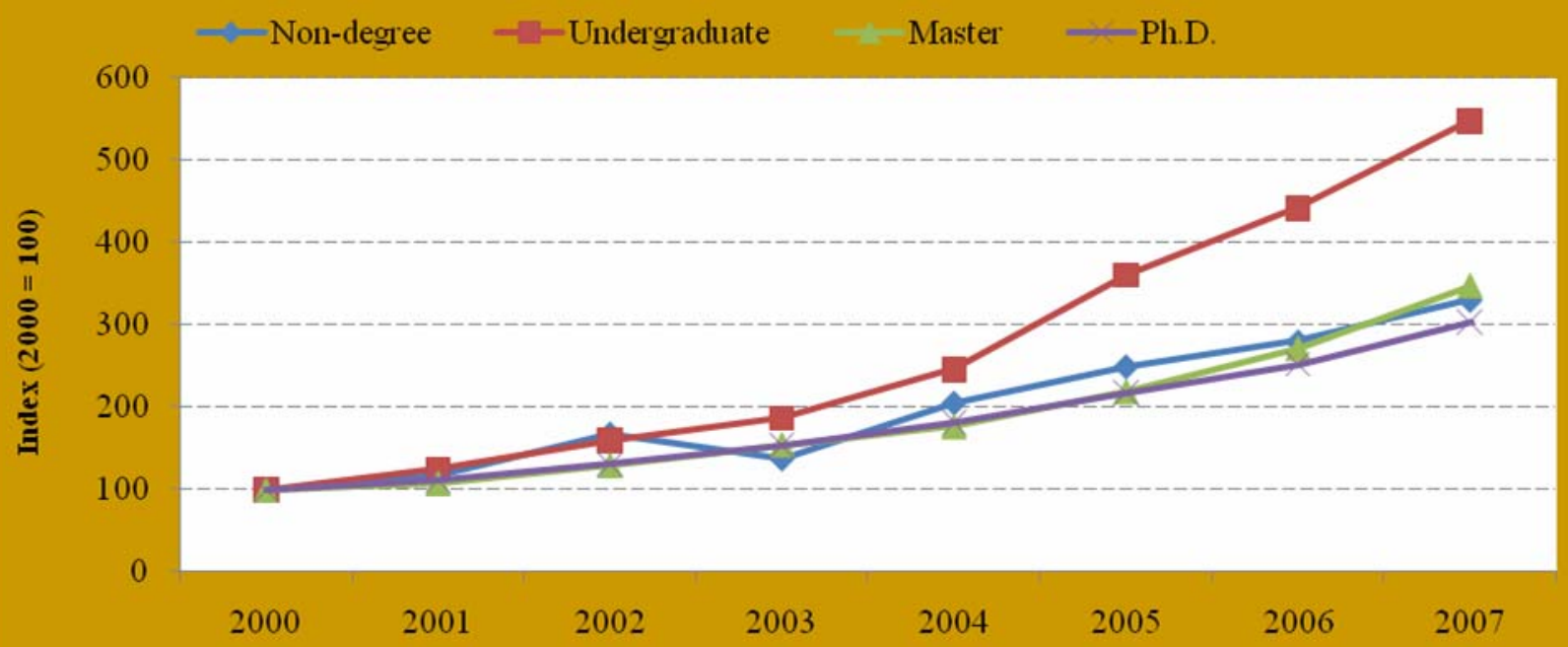

Source: China Education Yearbook, 2001-2008 Editions; own calculation 
Figure 14: Number of International Student by Field of Study in China: 2007

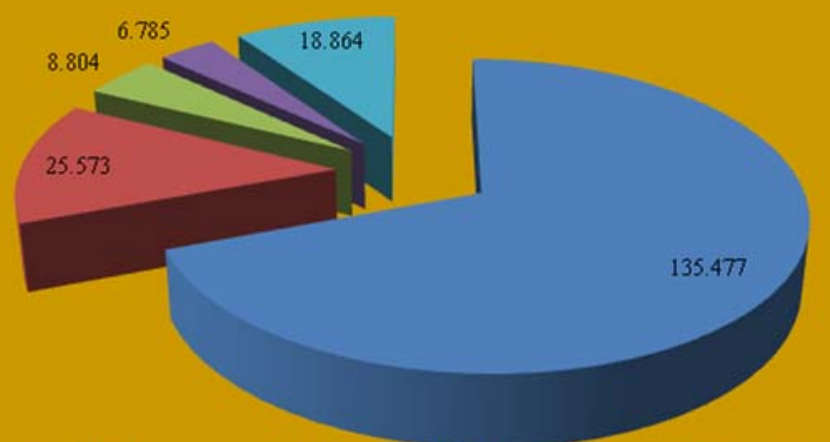

" Liberal Arts (incl. Chinese)

= Medicine (incl. Chinese and Western)

Economy

Engineering

Others*

Note: * incl.: Management, Law, Education, Science, History, Agriculture, Philosophy

Source: Ministry of Education of People's Republic of China; own presentation 